\title{
Towards the environmental sustainability assessment for the viticulture
}

\author{
Lucia Recchia, ${ }^{1}$ Daniele Sarri,, ${ }^{2}$ Marco Rimediotti, ${ }^{2}$ Paolo Boncinelli, ${ }^{2}$ Enrico Cini, ${ }^{2}$ Marco Vieri ${ }^{2}$ \\ ${ }^{1}$ Department of Innovation and Information Engineering, Guglielmo Marconi University, Roma; \\ ${ }^{2}$ Department of Management of Agricultural, Food and Forestry Systems, University of Firenze, Italy
}

\begin{abstract}
During the last decades in Italy the wine sector focused on the environmental sustainability of the production processes, including the agricultural, the agro-industrial and the packaging phases. Recent surveys highlighted that the wine consumers are interested in the environmental certifications, even if they are not familiar with them. Several environmental pressures can be evaluated in the viticulture phase, but an elevated number of the analysed impacts require the collection of a large set of input data and significant efforts during the elaboration phase. Therefore, the aim of the present work was the identification of the inventory data and impacts, which mainly describe the environmental pressures associated with the viticulture phase. Particularly, the results of the life cycle assessment (LCA) were integrated with those of a model and a simplified approach for evaluating the risks due to the pesticides use.

The LCA identified three phases, which are responsible of 70$80 \%$ of the $\mathrm{CO}_{2}$ eq $\left(\mathrm{CO}_{2}\right.$ equivalent), the cumulated energy utilisation, the acidification potential (expressed in $\mathrm{SO}_{2}$ equivalent) and the eutrophication (expressed in $\mathrm{PO}_{4}$ equivalent), i.e. the harvesting, the crop protection and the ligature. The phase of the pesticides use was analysed also through the pesticides risk indicator (PERI) model and a simplified approach elaborated by the Regional Agency for the Environment Protection in Tuscany, Italy.
\end{abstract}

Correspondence: Lucia Recchia, Department of Innovation and Information Engineering, Guglielmo Marconi University, via Plinio 44, 00193 Roma, Italy.

Tel.: +39.06.377251. E-mail: 1.recchia@unimarconi.it

Key words: Viticulture; pesticides; environmental sustainability; life cycle assessment; risks assessment.

Contributions: the authors contributed equally.

Conflict of interests: the authors declare no potential conflict of interest.

Received for publication: 10 August 2017.

Accepted for publication: 21 July 2017.

(C) Copyright L. Recchia et al., 2018

Licensee PAGEPress, Italy

Journal of Agricultural Engineering 2018; XLIX:586

doi:10.4081/jae.2018.586

This article is distributed under the terms of the Creative Commons Attribution Noncommercial License (by-nc 4.0) which permits any noncommercial use, distribution, and reproduction in any medium, provided the original author(s) and source are credited.
Results concerning the environmental risk showed that the PERI model, the Arpat approach and the LCA were coherent for the pesticide mix highlighting that the associated environmental risk is more than doubled from 2004 to 2010. Finally, some operative indications were elaborated in order to reduce the impacts and improve the local and global environmental sustainability of the viticulture phase.

\section{Introduction}

The wine production is one of the most sensible sectors to the environmental sustainability: during the last decades several studies (Pizzigallo et al., 2008; Notarnicola et al., 2010; Saxe, 2010; Bosco et al., 2011; Vázquez-Rowe et al., 2013) implemented different assessment methodologies and consequently promoted different approaches for claims, labels and certifications development. All these efforts are explained by the market responses to the green commitment of the companies (Sacchelli et al., 2016). A survey published by the California Wine Institute in 2013 (Wine trade and consumers surveys on sustainable winegrowing, http://www.sustainablewinegrowing.org) reports that the $34 \%$ of the wine consumers considers the environmental or sustainable attributes at the point of purchase. Moreover, the $66 \%$ of these wine consumers identifies the sustainable attributes through labels and information on the shelf or in store. Even if in Europe a specific survey for the wine consumers was not carried out, in 2009 the Eurobarometer analytical report (Eurobarometer, 2009) pointed out that the European citizens declare the importance of ecolabels in purchasing decisions (47\%) and think that the carbon footprint of the products should be mandatory (72\%). In the Italian market, the results of a Master Thesis in Agriculture (Lattanzi D, Le certificazioni ambientali nel mercato del vino: un caso studio del centro Italia, Tesi di Laurea magistrale in Scienze Alimentari ed Enologia, Università degli Studi di Firenze, 2013, unpublished data) highlighted that: i) only a third $35 \%$ of consumers is familiar with the environmental certifications in food; ii) more than $60 \%$ of consumers does not believe that wine is produced in an environmental responsible way; iii) consumers prefer wines with a sustainability certification or low environmental impact; iv) consumers are more interested in environmental certification for low and middle price products.

Considering all these assumptions the certification or evaluation of the wine sustainability is emerging at a global and national level. South Africa (e.g., SWSA, Sustainable Wine South Africa certification), New Zealand (e.g., SWNZ, Sustainable Winegrowers New Zeland certification, Grove Mill brand), Australia (e.g., Wolf Blass brand) and California (e.g., CSWA California Sustainable Winegrowing Alliance certification) wines show some examples of the sustainability volunteer certifications around the world. In Italy, with the aim to promote the sustainabil- 
ity of the wine sector in a homogeneous way, some projects have been developed: the V.I.V.A. Sustainable Wine project, the Tergeo project for the viticulture optimisation, the Eco-Prowine European project. Besides, other Italian wineries have worked for improving their environmental sustainability developing their specific code and label (e.g., Salcheto and Franciacorta brands). In addition, the International Organisation for Vineyards and Wine wrote specific guidelines for promoting a sustainable viticulture from the environmental, economic and social point of view (Falcone, 2016).

Such management could produce a lot of confusion and uncertainty in the consumers, which hardly understand the technical terms and the differences between the labels or the claims. Moreover, Vázquez-Rowe et al. (2013) highlighted that the same typology of product may have different environmental performances because of different influencing factors (e.g., geographical, technological and methodological aspects) and the agricultural phase is usually characterised by high variability. Therefore, considering that the model of the agricultural phase is a critical issue for the assessment of the agri-food chains, the present work aims to assess the environmental performances of the viticulture phase, evaluating some of its major impacts. Although the carbon footprint calculation is indicated as the most useful mean for assuring an effective communication from business to consumer and an easy utilisation by the stakeholders of the sector (Eurobarometer, 2009; Vázquez-Rowe et al., 2013), it does not allow to implement an integrated approach for an holistic evaluation of the environmental pressures due to the wine production. For all these reasons, the present work limits its system boundaries to the viticulture phase and uses the life cycle assessment (LCA) for monitoring the carbon footprint as well as the primary energy consumption, the acidification potential, the eutrophication, the total water requirement and the ecotoxicity effects due to the pesticides use.

However, considering that the pesticides use strongly decreased the water quality (Arpat, 2015), the integration of LCA methodology with other environmental analysis is very useful (Spugnoli et al., 2009; Recchia et al., 2011; Potting et al., 2012) with the purpose of simplifying the study implementation or the results interpretation. In this case the LCA was integrated with a risk assessment (RA) model, focusing on the evaluation of risks from non-accidental releases of pesticides to the environment and using the pesticides risk indicator (PERI) model and a simplified approach elaborated in Arpat (2015).

\section{Materials and methods}

The experimental data of the viticulture activities were collected in the Villa Montepaldi farm located in San Casciano Val di Pesa, Firenze, Italy $\left(43^{\circ} 68^{\prime} \mathrm{N} ; 1^{\circ} 14^{\prime} \mathrm{E}\right)$ in the northern part of the Chianti Classico wine production district. Covering an area of 315 hectares, the estate is characterized by some consolidated plots placed near to the transformation buildings. The farm management foresaw the fulfilment of the ordinary stages of a conventional hillside vineyard ( $8 \%$ average slope) with a planting layout of $2.5 \mathrm{~m}$ between the rows and 0.8 to $1 \mathrm{~m}$ on the lines (3200-5000 vines per hectare). Concerning the data, the 2010 inventory included all the agricultural inputs of the phase, whilst in 2004 only the data concerning the treatment against pest diseases were detected (Cerruto et al., 2016). Particularly, the data collected in 2010 were used for implementing a LCA methodology, while the data describing the pesticides application either in 2004 either in 2010 were mainly needed for the pesticides risk assessment implementation. The work refers only to these two years of production because for these two years the methodology of data collecting was the same: no farmer questionnaires or data reported in the farm registers were used but only data directly collected at least once a week by operators involved in the research activity.

\section{Life cycle assessment methodology}

Figure 1 illustrates the main inputs, the agricultural operations and the outputs, i.e. the product and the macro-categories of the emissions taken into account in the present work for the LCA
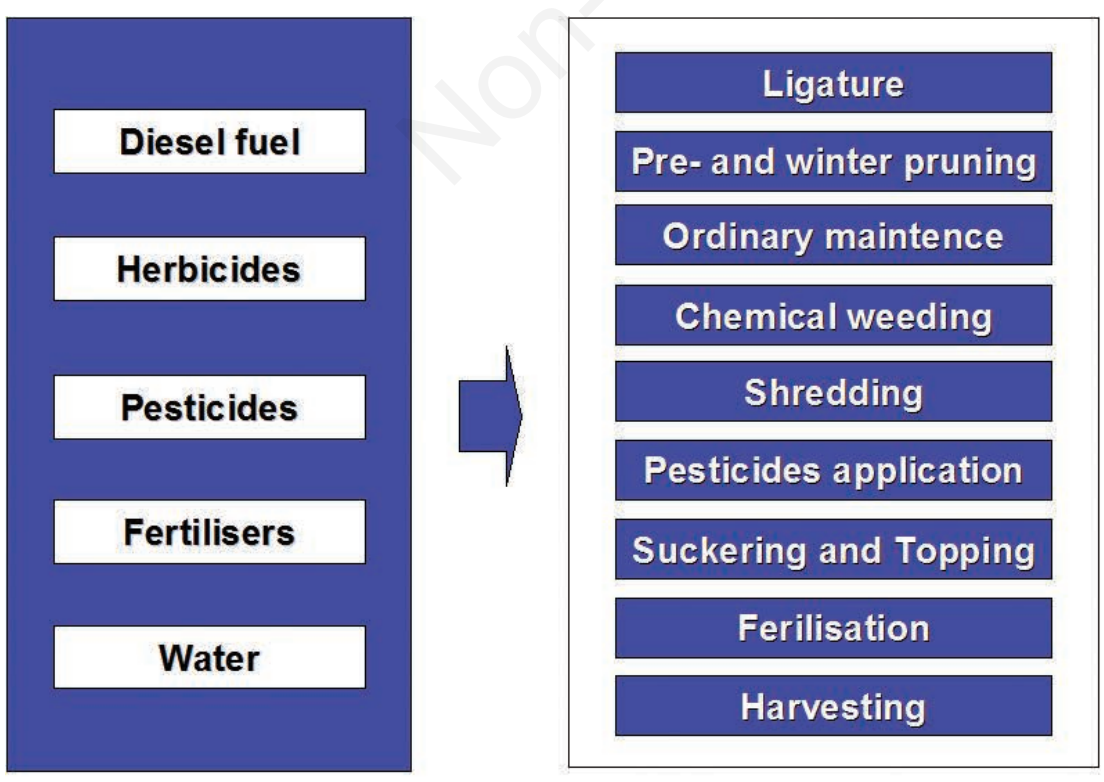
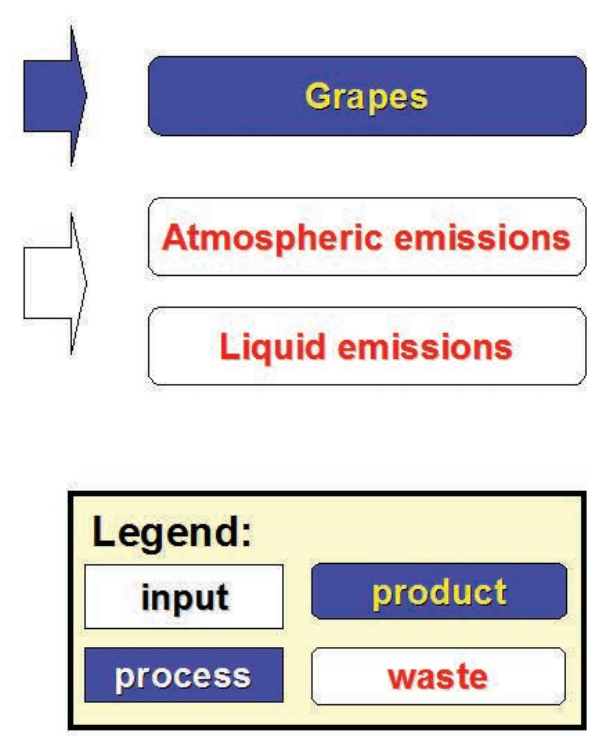

Figure 1. System boundaries of the viticulture phase for the life cycle assessment implementation. 
development. The adopted approach provides several exclusions for the data collection and the inputs estimation: i) all the nursery operations were not considered and, consequently, the impacts due to the vines growth before planting, were not considered (Vázquez-Rowe et al., 2013); ii) the vines planting phase was neglected because of the lack of experimental data. For this phase, the introduction of literature data was avoided in order to limit additional uncertainties in the LCA (Falcone et al., 2016). Moreover Bosco et al. (2011) and Vázquez-Rowe et al. (2013) indicate the low influence of the planting phase on the greenhous gases (GHG) emissions of the whole wine production chain, i.e. $5 \%$ of the total emissions, even if for the other indicators Falcone et al. (2016) highlight: i) heterogeneous results depending on the accuracy of the available data for the mechanical operations and the plants nursery; ii) no transports associated to fertilisers and other agrochemicals delivered to the farm were considered, taking into account that the sellers of these compounds may differ from year to year and no reliable information may be collected; iii) materials needed for the maintenance of the vineyards, e.g. wooden poles or wires for the ligature, were excluded as well as the construction materials of farm buildings and machines (Chiaramonti and Recchia, 2010); iv) the pruning residues and their final destination were not considered, even if the pruning phase is included within the system boundaries; v) energy and resources consumptions due to the administrative activities were not included.

Concerning the LCA implementation, the ISO 14040 methodology (ISO 14040:2006; ISO 14044:2006) was applied for determining the following environmental pressures: the effects on the global warming through the quantification of the $\mathrm{CO}_{2}$ equivalent emissions $\left(\mathrm{CO}_{2} \mathrm{eq}\right)$ considering the carbon dioxide $\left(\mathrm{CO}_{2}\right)$, the methane $\left(\mathrm{CH}_{4}\right)$ and the nitrous oxide $\left(\mathrm{N}_{2} \mathrm{O}\right)$ emissions and using the global warming potential GWP100 factors as defined in the Third Assessment Report of the IPCC (2001); the primary energy consumption through the cumulated energy utilisation (CEU), representing the fossil energy required for extracting, manufacturing and disposing raw and auxiliary materials all along each production chain; the acidification through the calculation of the $\mathrm{SO}_{2}$ equivalent $\left(\mathrm{SO}_{2} \mathrm{eq}\right)$ emissions considering nitrogen oxides, hydrogen fluoride, hydrogen chloride, sulphur dioxide, hydrogen sulphide and ammonia; the eutrophication as a measure of excessive nutrient intake into ecosystems through the calculation of the $\mathrm{PO}_{4}$ equivalent emissions $\left(\mathrm{PO}_{4} \mathrm{eq}\right)$; the used water during the agricultural phase which estimates the water depletion.

These indicators were indicated in Petti et al. (2015) because of their high relevance in estimating the main environmental impacts for wine production.

Table 1 illustrates the conversion factors for the main inputs listed in the scheme of the Figure 1. In the present work, the soft- ware used for implementing the LCA was Gemis ${ }^{\circledR}$ (IINAS, Darmstadt, Germany; http://iinas.org/gemis.html), which consists of an analysis model to determine energy and material flows (including transports), and a database. It takes into account all processes from resource extraction (primary energy, raw materials) to final energy or material use, and also includes auxiliary energy and material uses as well as materials for constructing energy, material and transport systems. However, for accounting the pesticides impacts even the Usetox ${ }^{\mathrm{TM}}$ (USEtox International Center; http://www.usetox.org/) was applied. In fact, the Gemis ${ }^{\circledR}$ database considers the outputs of the pesticides use in terms of atmospheric emissions but does not supply any information about their diffusion in liquid effluent. Therefore, the impacts due to the pesticides distribution in the environment were estimated through Usetox $^{\mathrm{TM}}$, able of calculating characterisation factors for freshwater ecotoxicity (Henderson et al., 2011; Rosenbaum et al., 2011). Usetox ${ }^{\mathrm{TM}}$ assesses the toxicological effects of chemical compounds based on a cause-effect chain that links emissions to impacts considering three aspects: environmental fate, exposure and effects (Rosenbaum et al., 2008). Particularly, the Usetox ${ }^{\mathrm{TM}}$ implementation permitted the evaluation of the ecotoxicity potential Etox: the characterisation factor for aquatic ecotoxicity is expressed in comparative toxic units $\left(\mathrm{CTU}_{\mathrm{e}}\right)$ and provides an estimate of the potentially affected fraction of species (PAF) integrated over time and volume per unit mass of a chemical emitted (PAF $\cdot \mathrm{m}^{3} \cdot$ day per $\mathrm{kg}$ ). In order to calculate this indicator, based on average losses of $10 \%$ and $30 \%$ to air and soil respectively for an air blast sprayer, the emissions to air and agricultural soil were considered (Pergher and Gubiani, 1996; Russu et al., 2003; Rimediotti and Vieri, 2009; Carli et al., 2010; Olesen and Jensen, 2013; Sarri, 2014).

No weighting rules were applied to the obtained results. In fact, weighting uses numerical factors based on value-choices to compare and aggregate the indicators outputs, which are not comparable on a physical basis. This option was considered not adequate for a comprehensive and transparent evaluation of the environmental pressures because of the lack concerning the relative importance of the each impact category.

Considering an average annual production of $1720 \mathrm{hL}$ from about 32 ha of vineyard in the Montepaldi farm with a hypothesised lifetime of 30 years (Cerutti et al., 2014), the functional unit is the amount of grape needed for producing the wine contained in a bottle of wine of $0.750 \mathrm{~L}$. This functional unit is very common, also for studies, which only refer to the viticulture phase (Petti et al., 2015).

The geographical region in focus for the wine production is mainly Tuscany, Italy.

In order to carry out the inventory of the data of the whole viticulture phase, a census of the agricultural machines and the trac-

Table 1. Conversion factors of the main inputs for calculating the environmental indicators in the life cycle assessment. For the $\mathrm{CO}_{2} \mathrm{eq}$ the GWPs of 1 for $\mathrm{CO}_{2}$, of 296 for the $\mathrm{N}_{2} \mathrm{O}$ and of 23 for $\mathrm{CH}_{4}$ were assumed; for the $\mathrm{SO}_{2}$ eq the $\mathrm{APs}$ of 1 for $\mathrm{SO}_{2}$, of 0.696 for $\mathrm{NO}_{\mathrm{x}}$, of 1.601 for $\mathrm{HF}$, of 0.878 for $\mathrm{HCl}$, of 0.983 for $\mathrm{H} 2 \mathrm{~S}$ and of 3.762 for $\mathrm{NH}_{3}$ were used; for the $\mathrm{PO}_{4}$ eq the conversion factor of 0.130 for $\mathrm{NOx}$ and 0.346 for $\mathrm{NH}_{3}$ were set.

\begin{tabular}{lcccccc} 
& $\mathrm{CO}_{2} \mathrm{eq}$ & $\mathrm{CEU}$ & $\mathrm{SO}_{2} \mathrm{eq}$ & $\mathrm{PO}_{4} \mathrm{eq}$ & Water & Gemis 4.71 process \\
Diesel fuel & $84 \mathrm{~g} \mathrm{MJ}^{-1}$ & $1.11 \mathrm{MJ} \mathrm{MJ}^{-1}$ & $0.83 \mathrm{~g} \mathrm{MJ}^{-1}$ & $0.13 \mathrm{~g} \mathrm{MJ}^{-1}$ & $0.01 \mathrm{~kg} \mathrm{MJ}^{-1}$ & dieselmotor-EU-agriculture-2000 (end-energy) \\
Pesticides & $122^{\prime} 320 \mathrm{~g} \mathrm{~kg}^{-1}$ & $193.92 \mathrm{MJ} \mathrm{kg}^{-1}$ & $37.70 \mathrm{~g} \mathrm{~kg}^{-1}$ & $2.21 \mathrm{~g} \mathrm{~kg}^{-1}$ & $32.37 \mathrm{~kg} \mathrm{~kg}^{-1}$ & chem-inorglpesticides-2000 \\
\hline $\mathrm{N}$-fertiliser & $7{ }^{\prime} 580 \mathrm{~g} \mathrm{~kg}^{-1}$ & $50.80 \mathrm{MJ} \mathrm{kg}^{-1}$ & $28.57 \mathrm{~g} \mathrm{~kg}^{-1}$ & $6.03 \mathrm{~g} \mathrm{~kg}^{-1}$ & $2.18 \mathrm{~kg} \mathrm{~kg}^{-1}$ & chem-inorglfertilizer-N-DE-2000 \\
$\mathrm{P}_{2} \mathrm{O}_{5}$-fertiliser & $274 \mathrm{~g} \mathrm{~kg}^{-1}$ & $4.06 \mathrm{MJ} \mathrm{kg}^{-1}$ & $4.10 \mathrm{~g} \mathrm{~kg}^{-1}$ & $0.28 \mathrm{~g} \mathrm{~kg}^{-1}$ & $1.90 \mathrm{~kg} \mathrm{~kg}^{-1}$ & chem-inorglfertilizer-P-2000 \\
\hline $\mathrm{K}_{2} \mathrm{O}$-fertiliser & $497 \mathrm{~g} \mathrm{~kg}^{-1}$ & $7.95 \mathrm{MJ} \mathrm{kg}^{-1}$ & $0.72 \mathrm{~g} \mathrm{~kg}^{-1}$ & $0.01 \mathrm{~g} \mathrm{~kg}^{-1}$ & $25.26 \mathrm{~kg} \mathrm{~kg}^{-1}$ & chem-inorglfertilizer-K-2000 \\
Water & $399 \mathrm{mg} \mathrm{kg}^{-1}$ & $0.01 \mathrm{MJ} \mathrm{kg}^{-1}$ & $0.52 \mathrm{mg} \mathrm{kg}^{-1}$ & $0.05 \mathrm{mg} \mathrm{kg}^{-1}$ & $1.00 \mathrm{~kg} \mathrm{~kg}^{-1}$ & xtra-drinking waterLDE-2000 \\
\hline
\end{tabular}


tors used for the vineyards operations was developed. In addition, based on the working gross time of each operation, an estimation of the required fuel was obtained implementing the Equation (1), which allows the calculation of the diesel consumption $(D C)$ in $\mathrm{kWh}$.

$D C=N D P \times A E L \times U T \times S F C \times L H V$

where $N P D$ is the nominal power of the tractor, expressed in kilowatt $(\mathrm{kW}), A E L$ is the average tractor engine load in the considered operation and implement type (\%), UT is the used time expressed in hours (h), $S F C$ is the specific fuel consumption $\left(\mathrm{kg} \mathrm{kWh}^{-1}\right)$, $L H V\left(\mathrm{kWh} \mathrm{kg}^{-1}\right)$ is the low value of the fuel heating. Particularly, SFC was calculated following the methodology defined by ASAE D497.7. standard (ASABE, 2015) that resulted in a range between 0.210 to $0.253 \mathrm{~kg} \mathrm{kWh}^{-1}$. AEL values were estimated assuming the maximum power required by the implements activation (data provided by implement manufacturer) in a hillside scenario (maximum slope $8 \%$ ). Finally, for the $L H V$ a value of $11.86 \mathrm{~kg} \mathrm{kWh}^{-1}$ was set. Moreover, the atmospheric emissions due to the use of the agricultural machines were accounted in the inventory. Table 2 reports the considered values of $A E L$ and $S F C$; for the winter pruning an agricultural daily yard with 4 workers equipped with pneumatic scissors requiring about $200 \mathrm{Wh} \mathrm{day}^{-1}$ was taken into account.

Concerning the amounts of crop protection and weed control products based on the percentage of the active principle, the dose and the land treated were calculated. Moreover, an average consumption of dilution water of about $100 \mathrm{~L} \mathrm{ha}^{-1}$ was considered for the distribution of these chemical compounds.

A similar approach was followed for estimating the total amount of the used fertilisers. Particularly, for the nitrogen supply, also the associated $\mathrm{N}_{2} \mathrm{O}$ emissions in field were assessed (Rafique et al., 2011).

Finally, the LCA results were evaluated identifying the key parameters and varying the input values of the baseline scenario (Huijbregts, 1998). Particularly, few different data were investigated as to their consequences for the model results: a limited number of scenarios with specific but consistent realizations of each parameter were defined and the associated results were calculated.

\section{Risk assessment methodology}

One of the most pollutant phases perceived by the consumers is the pesticide spraying and furthermore the market provides new solutions without supplying transparent and exhaustive information about the expected environmental benefits and drawbacks. Therefore, in order to analyse deeply the environmental consequences of the pesticides use, the PERI model was applied on two different chemicals mix adopted by the Montepaldi farm in 2004 and 2010. Such choice was based on the results achieved by Reus et al. (2002) where eight different approaches are compared. The PERI model was developed as a tool for farmers and advisers to select pesticides with the least environmental impact, allowing an assessment of the environmental pressures at farm level with the implementation of simpler algorithms. However, its implementation requires significant efforts and skills for analysing all the active chemicals used and its effects on the environment, i.e. on soil, water and organisms. Therefore, also a simplified approach elaborated by the Regional Agency for the Environment Protection in Tuscany, Italy, was tested. This approach may be very useful for the farmers either in the usable pesticides evaluation stages, but also for claiming the improvements in reducing their impacts on the biosphere.

In fact, this model is able to estimate the chemical properties of the pesticides, assessing their toxicity in the soil, the water and the air through the environmental risk ER calculated as reported in the Equation (2):

$E R=$ [GUS score $*$ Henry's constant score + (Mean toxicity score * Kow score) / 10]* Dose

where the scores were calculated based on the rules reported in Table 3 for the parameters considered in the following: i) the GUS is the leaching potential index; ii) the Henry's constant provides an indication of the preference of a chemical for air relative to water, i.e. its volatility; iii) the Mean toxicity is obtained as arithmetical mean between the scores of the $L_{50} / E C_{50}$ Daphnia, LC $C_{50}$ Earthworm, LD50 Bees; iv) the Kow is the ratio between the equilibrium concentration of a substance in n-octanol and its concentration in water.

Table 2. Definition of the maximum power request, its average engine load of the tractor AEL [\%] and the specific fuel consumption $\mathrm{SFC}\left[\mathrm{kg} \mathrm{kWh}{ }^{-1}\right]$ for the agricultural operations.

\begin{tabular}{|c|c|c|c|c|c|}
\hline Agricultural operations & Yard description & $\begin{array}{l}\text { Tractor maximum } \\
\text { power [kW] }\end{array}$ & $\begin{array}{l}\text { Implement maximum } \\
\text { implement [kW] }\end{array}$ & $\begin{array}{l}\text { AEL } \\
{[\%]}\end{array}$ & $\begin{array}{c}\text { SFC } \\
{\left[\mathrm{kg} \mathrm{kWh}^{-1}\right]}\end{array}$ \\
\hline Ligature wires removing & Tractor couplet with wrap wire & 46.3 & 3 & 6.48 & 0.228 \\
\hline Pre-pruning & Tractor coupled with pre-pruners & 58.8 & 5 & 8.50 & 0.228 \\
\hline Ordinary maintenance & Tractor coupled with post-hole diggers & 58.8 & 15 & 25.51 & 0.228 \\
\hline Soil management & Tractor coupled with cultivators with flexible blades & 60.3 & 40 & 66.37 & 0.210 \\
\hline Chemical weeding & Tractor coupled with over-the-row spray boom & 46.3 & 6 & 13.00 & 0.228 \\
\hline Shredding & Tractor coupled with shredder & 58.8 & 45 & 76.53 & 0.210 \\
\hline Pesticides application & Tractor coupled with air-blast sprayer & 58.8 & 47 & 79.93 & 0.210 \\
\hline Fertilisation & Tractor coupled with spreader & 58.8 & 17 & 28.91 & 0.228 \\
\hline Suckering & Tractor coupled with desukerer & 58.8 & 5 & 8.50 & 0.228 \\
\hline Topping & Tractor coupled with blade pruner & 46.3 & 5 & 11.34 & 0.228 \\
\hline Harvesting & Self propelled grape harvester & - & 110 & 70.00 & 0.253 \\
\hline Transport & Tractor coupled with 3 tons grape trailer & 58.8 & 6 & 10.20 & 0.228 \\
\hline
\end{tabular}


Particularly, the GUS which indicates the substance mobility in the soil is calculated through the Equation (3), where DT50 is the time required for the chemical concentration under defined conditions to decline to $50 \%$ of the amount at application, and the organic-carbon sorption constant $K o c$ is obtained applying the Equation (4):

$G U S=\log D T 50^{*}(4-\log$ Koc $)$

$\log K o c=\log K o w-0.21$

As indicated in (Reus et al., 2002), the PERI model is one of the possible model developed for predicting the effects of the pesticides on the environment and the human health. This model was designed as a part of a system of indicators that could be used by farmers to record and evaluate possible environmental risk over time: it uses a ranking methodology that assesses chemical properties of the pesticide and toxicity values.

The Henry's constant provides an indication of the preference of a chemical for air relative to water i.e., its volatility; the Kow indicates the hydrophobicity of the compound. Moreover, the model considers the mean toxicity of the different environmental compartments, i.e. water, soil and air in terms of specific concentrations under a defined set of conditions as regard Daphnia, Earthworm and Bees.

All the parameters used for the PERI model implementation were collected from several sources and databases: i) the DT50, the Henry's constant, the Kow, the EC $C_{50}$ Daphnia, the LC $C_{50}$ Earthworm and the $L D_{50}$ Bees were collected from the Pesticide Properties DataBase (PPDB) developed by the University of Hertfordshire (http://sitem.herts.ac.uk/aeru/footprint); ii) the LC50 Daphnia was obtained from the ISPRA database (http://www. isprambiente.gov.it/contentfiles/00007800/), the Handbook of pesticide toxicology (Academic Press, Orlando, FL; 2001), some safety data sheets and, alternatively, implementing the EPA software TEST.

Finally, the model includes the distributed Dose expressed in $\mathrm{kg}$ per ha.

Moreover, based on (Arpat, 2015) the simplified approach elaborated by the Regional Agency for the Environment Protection in Tuscany, Italy (hereinafter Arpat model) was implemented. The Arpat model defines three different indicators, i.e. the overall impact, the water impact and the ecosystem impact, aggregating the similar parameters used for the PERI model implementation. However in Arpat (2015) a useful list of the most common active chemicals is reported indicating for each one the three impacts' indicators which are assumed equal to zero for sulphur or copper based compounds.

\section{Results and discussion}

Table 4 reports the input data used for the LCA implementation, i.e. the amounts of diesel fuel, herbicides, pesticides, fertilisers and water. Considering the huge consumption of the diesel fuel, a specific analysis of this input was developed: Figure 2 illustrates the diesel used for each month and agricultural operation in 2010.

From a quantitative point of view, the major input of the viticulture phase was the water, mainly required for the pesticides distribution, followed by the diesel fuel and the pesticides amounts. Particularly, the inventory illustrates that about $0.543 \mathrm{~L}$ of water were needed for the grapes able to produce $0.750 \mathrm{~L}$ of wine, confirming that a water footprint approach will be more and more essential if the environmental sustainability of the wine is pursued (Bonamente et al., 2016).

The huge diesel requirement is due to the high level of mechanisation and also to the management choices: the fuel consump-



Figure 2. Diesel consumptions for each month and for each agricultural operation in 2010.

Table 3. Method for scores assignment to the parameters of the PERI model.

\begin{tabular}{|c|c|c|c|c|c|c|}
\hline Score & GUS & Henry's constant & Kow & $L C_{50} / E C_{50}$ Daphnia & $L C_{50}$ Earthworm & $L C_{50}$ Bees \\
\hline 1 & $\leq 0$ & $<1$ & $<3.0$ & $>100 \mathrm{mg} \mathrm{L}^{-1}$ & $>1000 \mathrm{mg} \mathrm{kg}^{-1}$ & $>100$ mg per Bee \\
\hline 2 & $(0.0 ; 1.0]$ & {$[1 ; 5]$} & - & $(10 ; 100] \mathrm{mg} \mathrm{L}^{-1}$ & $(100 ; 1000] \mathrm{mg} \mathrm{kg}^{-1}$ & $(10 ; 100]$ mg per Bee \\
\hline 3 & $(1.0 ; 1.8]$ & $(5 ; 25]$ & - & $(1 ; 10] \mathrm{mg} \mathrm{L}^{-1}$ & $(10 ; 100] \mathrm{mg} \mathrm{kg}^{-1}$ & $(1 ; 10]$ mg per Bee \\
\hline 4 & $(1.8 ; 2.8]$ & $(25 ; 100]$ & - & $(0.1 ; 1.0] \mathrm{mg} \mathrm{L}^{-1}$ & $(1 ; 10] \mathrm{mg} \mathrm{kg}^{-1}$ & $(0.1 ; 1.0]$ mg per Bee \\
\hline 5 & $>2.8$ & $>100$ & $\geq 3.0$ & $\geq 0.1 \mathrm{mg} \mathrm{L}^{-1}$ & $\leq 1 \mathrm{mg} \mathrm{kg}^{-1}$ & $\leq 0.1 \mathrm{mg}$ per Bee \\
\hline
\end{tabular}


tion directly depends on the working hours and the power of the machines used. Therefore, with the aim to understand the agricultural operations responsible of the major consumptions of the diesel, an analysis of the field works was carried out. Results demonstrated that the harvesting determines the higher contribution $(49 \%)$, followed by the pesticides application $(22 \%)$ and the ligature $(10 \%)$. These indications may help farmers for reducing the fuel consumptions: it will be useful knowing the machines used for each operation and their energy requirements, using new and more efficient equipment, converting of the engines of some machines from fossil diesel to biofuel, promoting different managements of the vineyards (e.g., reducing mechanical operations).

Table 5 reports the LCA results calculated for the functional unit, i.e. the amount of grape necessary for producing a bottle of wine of $0.750 \mathrm{~L}$ : in order to identify the most pollutant phase, the results of each agricultural operation have been calculated. The obtained results showed that the most influencing input data is the diesel consumption, which impacts all the agricultural operations. Particularly, for the $\mathrm{CO}_{2}$ eq indicator, the pesticides application and the harvesting phases, followed by the ligature, are the most pollutant, according to the high diesel requirement and the use of chemical compounds. These three phases determine the $82 \%$ of the total $\mathrm{CO}_{2}$ eq. Similar results were obtained for the assessment of the

Table 4. Inventory data per functional unit for the vineyard management in 2010.

\begin{tabular}{lcc} 
Input & {$[\mathrm{kg}]$} & {$[\mathrm{g}$ per FU] } \\
Diesel & 12,015 & 52.550 \\
Herbicides & 35 & 0.153 \\
\hline Pesticides & 1710 & 7.456 \\
$\mathrm{~N}$-fertiliser & 64 & 0.280 \\
\hline $\mathrm{P}_{2} \mathrm{O}_{5}$-fertiliser & 43 & 0.187 \\
$\mathrm{~K}_{2} \mathrm{O}-$ fertiliser & 86 & 0.374 \\
\hline Water & 124,493 & 542.847 \\
\hline
\end{tabular}

Table 5. Results of the life cycle assessment for the vineyard management in 2010 . All the values are referred to the functional unit.

\begin{tabular}{|c|c|c|c|c|c|c|c|c|c|c|}
\hline $\begin{array}{l}\text { Impact } \\
\text { Indicator }\end{array}$ & & & $\begin{array}{c}\text { C } \\
\text { MJ f }\end{array}$ & & & & $\begin{array}{r}\text { Eutro } \\
\text { P }\end{array}$ & ation & $\mathrm{Blt}$ & \\
\hline & [g] & [\%] & [MJ] & [\%] & [g] & {$[\%]$} & [g] & {$[\%]$} & {$[g]$} & {$[\%]$} \\
\hline Ligature & 17.96 & 8 & 0.24 & 10 & 0.18 & 9 & 0.028 & 9 & 1.73 & 0 \\
\hline Pre-pruning & 0.78 & 0 & 0.01 & 0 & 0.01 & 0 & 0.001 & 0 & 0.08 & 0 \\
\hline Winter pruning & 1.95 & 1 & 0.03 & 1 & 0.02 & 1 & 0.003 & 1 & 0.19 & 0 \\
\hline Ordinary maintenance & 5.64 & 2 & 0.08 & 3 & 0.06 & 3 & 0.009 & 3 & 0.54 & 0 \\
\hline Chemical weeding & 4.39 & 2 & 0.03 & 1 & 0.03 & 2 & 0.004 & 1 & 46.68 & 7 \\
\hline Shredding & 16.67 & 7 & 0.22 & 9 & 0.16 & 8 & 0.026 & 9 & 1.60 & 0 \\
\hline Pesticides application & 77.63 & 34 & 0.54 & 22 & 0.51 & 26 & 0.069 & 23 & 603.20 & 89 \\
\hline Fertilisation & 3.64 & 2 & 0.00 & 0 & 0.01 & 1 & 0.002 & 1 & 10.44 & 2 \\
\hline Suckering & 7.45 & 3 & 0.10 & 4 & 0.07 & 4 & 0.011 & 4 & 0.72 & 0 \\
\hline Topping & 1.28 & 1 & 0.02 & 1 & 0.01 & 1 & 0.002 & 1 & 0.12 & 0 \\
\hline Harvesting & 93.72 & 41 & 1.24 & 50 & 0.92 & 46 & 0.144 & 48 & 9.01 & 1 \\
\hline Total & 231 & - & 2.5 & - & 2.0 & - & 0.3 & - & 674 & - \\
\hline
\end{tabular}

Table 6. Results of sensitivity analysis for the vineyard management in 2010 and of the life cycle assessment for the pesticides distribution in 2004 and in 2010.

\begin{tabular}{|c|c|c|c|c|c|c|c|c|}
\hline Impact & Indicator & \multicolumn{2}{|c|}{ Diesel consumption } & \multicolumn{2}{|c|}{ Herbi-pesticides consumption } & \multicolumn{3}{|c|}{ Yield } \\
\hline GHG & $\mathrm{CO}_{2} \mathrm{eq}$ & $-21 \%$ & $+21 \%$ & $-4 \%$ & $+4 \%$ & $+31 \%$ & & $-19 \%$ \\
\hline CEU & MJ fossil & $-25 \%$ & $+25 \%$ & $-1 \%$ & $+1 \%$ & $+30 \%$ & & $-18 \%$ \\
\hline $\mathrm{AP}$ & $\mathrm{SO}_{2} \mathrm{eq}$ & $-23 \%$ & $+23 \%$ & $-2 \%$ & $+2 \%$ & $+30 \%$ & & $-18 \%$ \\
\hline Eutrophication & $\mathrm{PO}_{4} \mathrm{eq}$ & $-24 \%$ & $+24 \%$ & $-2 \%$ & $+2 \%$ & $+33 \%$ & & $-20 \%$ \\
\hline WU & Blue Water & $-1 \%$ & $+1 \%$ & $-19 \%$ & $+19 \%$ & $+30 \%$ & & $-18 \%$ \\
\hline \multicolumn{4}{|l|}{ Pesticides } & \multicolumn{2}{|c|}{$\begin{array}{l}\text { Dose } \\
{\left[\mathrm{kg} \mathrm{ha}^{-1}\right]}\end{array}$} & \multicolumn{3}{|c|}{$\begin{array}{l}\text { Etox } \\
{[\text { CTUe] }}\end{array}$} \\
\hline \multicolumn{4}{|c|}{$\begin{array}{l}\text { Pesticides mix on } 2004 \\
\text { (Curzate RDF; Equation Sys; Idrorameflow; Karathane XFLC; } \\
\text { Kocide 200; Microthiol D; Reldan; Scala; Systhane 12E; } \\
\text { Thiamonplus; Sulphur B; Sulphur ventilated) }\end{array}$} & \multicolumn{2}{|c|}{70.82} & \multicolumn{3}{|c|}{0.15290} \\
\hline \multicolumn{4}{|c|}{$\begin{array}{l}\text { Pesticides mix on } 2010 \\
\text { (Airone; Avaunt EC; Brezza; Electis MZ; Forum R 3B; } \\
\text { Karathane star; Melody Trevi; Nimrod; Talendo; Vivando; Sulphur ventilated) }\end{array}$} & \multicolumn{2}{|c|}{51.23} & \multicolumn{3}{|c|}{0.51308} \\
\hline
\end{tabular}


cumulated energy use, the acidification and the eutrophication, where the ligature, the pesticides application and the harvesting weight for about the $80 \%$ of the total amount. For the water use, considering that no irrigation of the vineyards was hypothesised, the pesticides application was the main responsible of the resource depletion.

These results were validated through the literature sources: for instance, concerning the GHG emissions, the values for the viticulture phase in Italy is ranging between 80 and $240 \mathrm{gCO}_{2}$ eq per bottle in Bosco et al. (2011) or between 120 and $707 \mathrm{gCO}_{2}$ eq per bottle in Saxe (2010) and up to $267 \mathrm{gCO}_{2}$ eq per bottle in Bonamente et al. (2016), even if other sources report lower amounts (Pizzigallo et al., 2008; Notarnicola et al., 2010). However, these bibliographic data show an elevated variability of the calculations: generally, this variability does not occur because of the climatic or soil factors (Vázquez-Rowe et al., 2013), but mainly because of different farming management and different implementation of the LCA methodology (e.g., different system boundaries, different cutoffs, etc.).

A sensitivity analysis was carried out varying the yield and the diesel consumption as reported in Table 6. Moreover, also the amounts of the herbicides and pesticides were varied in order to focus the attention to the plant protection. Results highlighted that the LCA calculations are more sensitive to the yield and fuel variations than to chemicals amounts for plant protection. However, no correlations between yield and pesticides application were investigated: obviously different chemicals amounts may determine variations in the yield and in the calculated indicators.

The LCA implementation estimated also the Etox in 2004 and 2010, as reported in Table 6 .

Finally, Tables 7 and 8 respectively illustrate the results of the PERI and the Arpat models for the pesticides mix in 2004 and in

Table 7. Results of the PERI model for the vineyard management in 2004 and 2010.

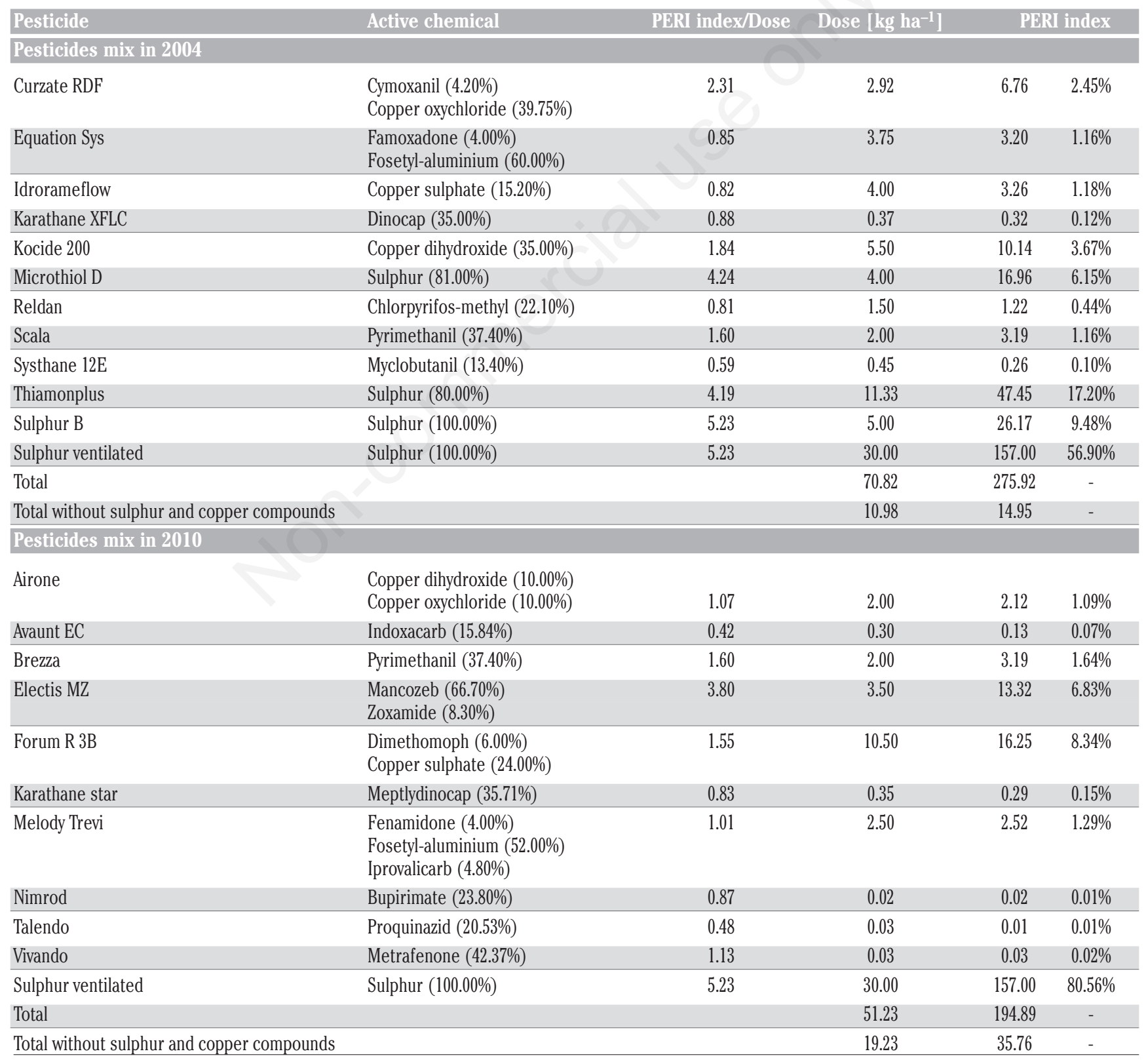


2010. In fact, taking into account that the pesticides use significantly weights on the LCA results and may cause important consequences on the environment, the additional RA was implemented through the PERI model and the Arpat simplified approach.

The results of the PERI model demonstrated that from 2004 to 2010 an important reduction of the dose of chemicals per hectare occurred. If the sulphur and copper based compounds are accounted in the model, a significant reduction of the PERI index (from 275.92 to 194.89 ) is also detectable. However, this reduction of the environmental risk is mainly due to the decreasing of the distributed dose, according to the higher efficacy of the adopted active substances. If chemicals allowed by the organic agriculture are considered not pollutant with an associated environmental risk equal to zero, the PERI index results more than doubled (from 14.95 in 2004 to 35.76 in 2010) according to the Etox calculations (from
0.153 CTUe in 2004 to 0.513 CTUe in 2010). Anyway, the use of the sulphur ventilated determines the most significant impact because of the high GUS, Kow and volatility, as well as the huge required dose on the field. Moreover, a simple comparison of the PERI indices for the active substances without considering the distributed amount per hectare, demonstrates that a very limited improvement in terms of the environmental sustainability occurred, as shown in Figure 3. The implementation of the Arpat approach also highlights a higher environmental risk associated to the pesticides mix proposed in 2010 , observing a risk nearly doubled (from 5.33 in 2004 to 10.14 in 2010).

Therefore, the Etox calculation, the PERI model and the Arpat approach noticed an increased environmental pressure on 2010 as regard as 2004, even if the reduction of the comprehensive dose per hectare was observed.

Table 8. Results of the Arpat model for the vineyard management in 2004 and 2010.

\begin{tabular}{|c|c|c|c|c|c|}
\hline Pesticide & \multicolumn{2}{|l|}{ Active chemical } & \multirow[t]{2}{*}{$\begin{array}{c}\text { Arpat index/Dose } \\
\text { Water impact }\end{array}$} & \multirow[t]{2}{*}{ Ecosystem impact } & \multirow[t]{2}{*}{ Dose $\left[\mathrm{kg} \mathrm{ha}^{-1}\right]$} \\
\hline \multicolumn{3}{|c|}{ Pesticides mix in 2004} & & & \\
\hline Curzate RDF & $\begin{array}{l}\text { Cymoxanil }(4.20 \%) \\
\text { Copper oxychloride }(39.75 \%)\end{array}$ & $\begin{array}{l}2.00 \\
0.00\end{array}$ & $\begin{array}{l}2.00 \\
0.00\end{array}$ & $\begin{array}{l}2.00 \\
0.00\end{array}$ & 2.92 \\
\hline Equation Sys & $\begin{array}{l}\text { Famoxadone }(4.00 \%) \\
\text { Fosetyl-aluminium }(60.00 \%)\end{array}$ & $\begin{array}{l}2.00 \\
1.00\end{array}$ & $\begin{array}{l}1.00 \\
2.00\end{array}$ & $\begin{array}{l}2.00 \\
1.00\end{array}$ & 3.75 \\
\hline Idrorameflow & Copper sulphate (15.20\%) & 0.00 & 0.00 & 0.00 & 4.00 \\
\hline Karathane XFLC & Dinocap (35.00\%) & 2.00 & 1.00 & 2.00 & 0.37 \\
\hline Kocide 200 & Copper dihydroxide (35.00\%) & 0.00 & 0.00 & 0.00 & 5.50 \\
\hline Microthiol D & Sulphur (81.00\%) & 0.00 & 0.00 & 0.00 & 4.00 \\
\hline Reldan & Chlorpyrifos-methyl (22.10\%) & 2.00 & 1.00 & 2.00 & 1.50 \\
\hline Scala & Pyrimethanil (37.40\%) & 2.00 & 2.00 & 2.00 & 2.00 \\
\hline Systhane 12E & Myclobutanil (13.40\%) & 2.00 & 3.00 & 2.00 & 0.45 \\
\hline Thiamonplus & Sulphur (80.00\%) & 0.00 & 0.00 & 0.00 & 11.33 \\
\hline Sulphur B & Sulphur (100.00\%) & 0.00 & 0.00 & 0.00 & 5.00 \\
\hline Sulphur ventilated & Sulphur (100.00\%) & 0.00 & 0.00 & 0.00 & 30.00 \\
\hline Arpat index & 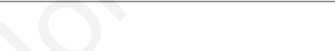 & 5.33 & 7.03 & 5.33 & - \\
\hline \multicolumn{6}{|c|}{ Pesticides mix in 2010} \\
\hline Airone & $\begin{array}{l}\text { Copper dihydroxide }(10.00 \%) \\
\text { Copper oxychloride }(10.00 \%)\end{array}$ & $\begin{array}{l}0.00 \\
0.00\end{array}$ & $\begin{array}{l}0.00 \\
0.00\end{array}$ & $\begin{array}{l}0.00 \\
0.00\end{array}$ & 2.00 \\
\hline Avaunt EC & Indoxacarb (15.84\%) & 2.00 & 1.00 & 2.00 & 0.30 \\
\hline Brezza & Pyrimethanil (37.40\%) & 2.00 & 2.00 & 2.00 & 2.00 \\
\hline Electis MZ & $\begin{array}{l}\text { Mancozeb }(66.70 \%) \\
\text { Zoxamide }(8.30 \%)\end{array}$ & $\begin{array}{l}2.00 \\
2.00\end{array}$ & $\begin{array}{l}1.00 \\
1.00\end{array}$ & $\begin{array}{l}2.00 \\
2.00\end{array}$ & 3.50 \\
\hline Forum R 3B & $\begin{array}{l}\text { Dimethomoph }(6.00 \%) \\
\text { Copper sulphate }(24.00 \%)\end{array}$ & $\begin{array}{l}2.00 \\
0.00\end{array}$ & $\begin{array}{l}2.00 \\
0.00\end{array}$ & $\begin{array}{l}2.00 \\
0.00\end{array}$ & 10.50 \\
\hline Karathane star & Meptlydinocap (35.71\%) & 2.00 & 1.00 & 2.00 & 0.35 \\
\hline Melody Trevi & $\begin{array}{l}\text { Fenamidone }(4.00 \%) \\
\text { Fosetyl-aluminium }(52.00 \%) \\
\text { Iprovalicarb }(4.80 \%)\end{array}$ & $\begin{array}{l}2.00 \\
1.00 \\
2.00\end{array}$ & $\begin{array}{l}2.00 \\
2.00 \\
2.00\end{array}$ & $\begin{array}{l}2.00 \\
1.00 \\
2.00\end{array}$ & 2.50 \\
\hline Nimrod & Bupirimate (23.80\%) & 2.00 & 2.00 & 2.00 & 0.02 \\
\hline Talendo & Proquinazid (20.53\%) & 2.00 & 2.00 & 2.00 & 0.03 \\
\hline Vivando & Metrafenone (42.37\%) & 2.00 & 2.00 & 2.00 & 0.03 \\
\hline Sulphur ventilated & Sulphur (100.00\%) & 0.00 & 0.00 & 0.00 & 30.00 \\
\hline Arpat index & & 10.14 & 8.64 & 10.14 & - \\
\hline
\end{tabular}




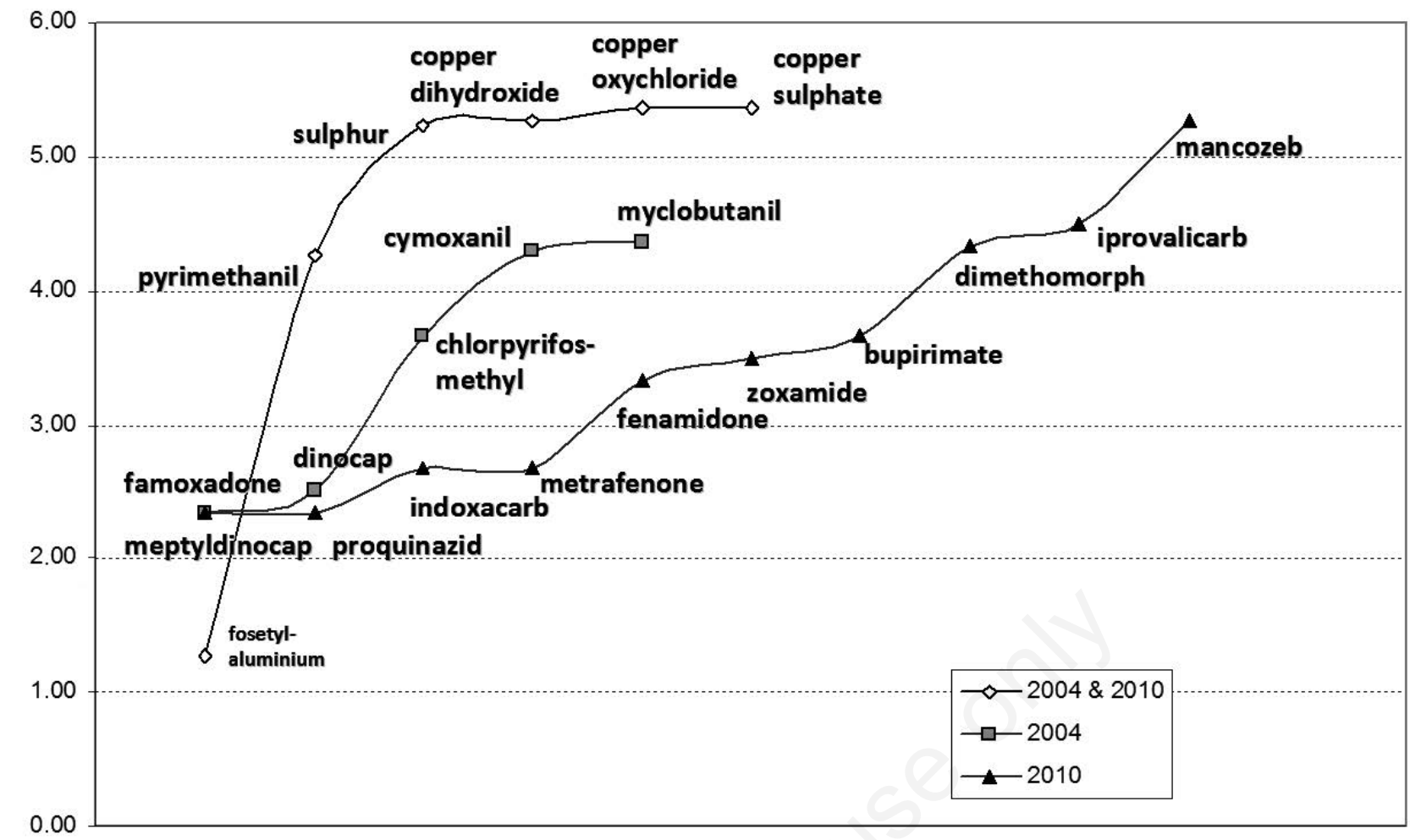

Figure 3. PERI index/Dose for each active substance used in 2004 and 2010.

\section{Conclusions}

The present work highlighted that the LCA approach may be effectively integrated with other assessment methods for a comprehensive evaluation of the environmental pressures due to the use of pesticides. According to the $\mathrm{CO}_{2} \mathrm{eq}$, the $\mathrm{CEU}$, the acidification potential and the eutrophication identified the harvesting, the ligature and the pesticides use as the most pollutant phases of the analysed system. Moreover, the results of the PERI model for the pesticides mix in 2004 and 2010 are coherent with the LCA results, if chemicals allowed in the organic agriculture are not accounted for the environmental risks. In fact, the Etox indicator and the PERI model according to the Arpat simplified approach highlighted that the associated environmental risk is more than doubled from 2004 to 2010 .

Therefore, an integration between the LCA and a specific RA methodology for evaluating the environmental pressures due to the pesticides use may be useful: results show that simplified models and approaches (i.e., the PERI model and the Arpat approach) were able to describe the environmental toxicity of the pesticides without developing a complete LCA model for the viticulture chain.

Moreover, the present work allowed to supply useful suggestions for farmers in order to reduce the impacts of the viticulture phase: i) the diesel consumption should be limited during the harvesting, the pesticides application and the ligature phases; ii) the reduction of the pesticides dose allows the decreasing of the water needed for their distribution; iii) the simplified and easy-to-implement Arpat approach may be very useful for farmers for identifying the less pollutant compounds.

\section{References}

Arpat (Regional Agency for Environment Protection of Tuscany, Italy). 2015. Fitofarmaci - Proposta di un indicatore di pressione elaborando proprietà ambientali e dati di utilizzo dei prodotti fitosanitari. Pubblicazione ARPAT, Regione Toscana, Firenze, Italy.

ASABE (American Society 680 of Agricultural and Biological Engineers). 2015. ASABE Standards, D497.7: Agricultural Machinery Management Data, 62 ${ }^{\text {th }}$ ed. American Society of Agricultural and Biological Engineers, St. Joseph, MI, USA.

Bonamente E., Scrucca F., Rinaldi S., Merico M.C., Asdrubali F., Lamastra L. 2016. Environmental impact of an Italian wine bottle: carbon and water footprint assessment. Sci. Total Environ. 560-561:274-83.

Bosco S., Di Bene C., Galli M., Remorini D., Massai R., Bonari E. 2011. Greenhouse gas emissions in the agricultural phase of wine production in the Maremma rural district in Tuscany, Italy. Ital. J. Agron. 6:6-15.

Carli M., Rimediotti M., Scarpi C., Vieri M. 2010. Effetto deriva e possible riduzione delle perdite aeree nella distribuzione dei prodotti fitosanitari. $8^{\circ}$ Convegno Nazionale Fitofarmaci e Ambiente, 12-13 maggio, Roma, Italy.

Cerutti A.K., Beccaro G.L., Bruun S., Bosco S., Donno D., Notarnicola B., Bounous G. 2014. Life cycle assessment application in the fruit sector: state of the art and recommendations for environmental declarations of fruit products. J. Clean Prod. 73:125-35.

Cerruto E., Failla S., Longo D., Manetto G. 2016. Simulation of water sensitive papers for spray analysis. Agricult. Engine. Int. 
CIGR J. 18:22-9.

Chiaramonti D., Recchia L. 2010. Is life cycle assessment (LCA) a suitable method for quantitative $\mathrm{CO}_{2}$ saving estimations? The impact of field input on the LCA results for a pure vegetable oil chain. Biomass Bioener. 34:787-97.

Eurobarometer. 2009. Europeans' attitudes towards the issue of sustainable consumption and production, Analytical report. The Gallup Organisation at the request of the EU DGEnvironment, Flash EB Series \#256, Hungary.

Falcone G., De Luca A.I., Stillitano T., Strano A., Romeo G., Gulisano G. 2016. Assessment of environmental and economic impacts of vine-growing combining life cycle assessment, life cycle costing and multicriterial analysis, sustainability. Sustainability 8:793-826.

Henderson A.D., Hauschild M.Z., van de Meent D., Huijbregts M.A.J., Larsen H.F., Margni M., McKone T.E., Payet J., Rosenbaum R.K., Jolliet O. 2011. USEtox fate and ecotoxicity factors for comparative assessment of toxic emissions in life cycle analysis: sensitivity to key chemical properties. Int. J. Life Cycle Assess. 16:701-9.

Huijbregts M. 1998. Application of uncertainty and variability in LCA, Part I: ageneral framework for the analysis of uncertainty and variability in life cycle assessment. Int. J. Life Cycle Assess. 3:273-80.

Notarnicola B., Tassielli G., Settanni E. 2010. Including more technology in the production of a quality wine: the importance of functional unit. Proceedings of LCA Food 2010, 22-24 September, Bari, Italy.

Olesen M.H., Jensen P.K. 2013. Collection and evaluation of relevant information on crop interception. EFSA Supporting Publication, EN-438. Available from: https:/www.efsa.europa.eu/en/supporting/pub/en-438

Pergher G., Gubiani R. 1996. Valutazione dell'efficienza di distribuzione di una irroratrice a getto portato mediante analisi fluorimetrica dei depositi. Atti Giorn. Fitopatol. I:487-94.

Petti L., Arzoumanidis I., Benedetto G., Bosco S., Cellura M., De Camillis C., Fantin V., Casotti P., Pattara C., Raggi A., Rugani B., Tasselli G., Vale M. (Eds.). 2015. Life cycle assessment in the wine sector, in life cycle assessment in the agri-food sector. Springer International Publishing, Berlin, Gernamy, pp. 123184.

Pizzigallo A.C.I., Granai C., Borsa S. 2008. The joint use of LCA and emergy evaluation for the analysis of two Italian wine farms. J. Environ. Manage. 86:396-406.

Potting J., Gheewala S., Bonnet S., van Buuren J. 2012. How to approach the assessment?, Chapter 18. In: M. A. Curran (Ed.), Life cycle assessment handbook: a guide for environmentally sustainable products. Scrivener Publishing LLC, Austin, TX, USA, pp. 391-412.

Rafique R., Hennessy D., Kiely G. 2011. Nitrous oxide emission from grazed grassland under different management systems. Ecosystems 14:563-82.

Recchia L., Boncinelli P., Sarri D., Cini E., Vieri M., Garbati Pegna F. 2011. Multicriteria analysis and LCA techniques - approach to agro-engineering problems, Monograph. Springer Publisher, Berlin, Germany

Reus J., Leendertse P., Bockstaller C., Fomsgaard I., Gutsche V., Lewise K., Nilsson C., Pussemier L., Trevisan M., van der Werf H., Alfarroba F., Blümel S., Isart J., McGrathm D., Seppälä T. 2002. Comparison and evaluation of eight pesticide environmental risk indicators developed in Europe and recommendations for future use. Agric. Ecosyst. Environ. 90:177-87.

Rimediotti M., Vieri M. 2009. Effetto deriva e possibile riduzione delle perdite aeree nella distribuzione dei fitofarmaci. ARPAT, Firenze, Italy.

Rosenbaum R.K., Bachmann T.M., Swirsky Gold L., Huijbregts M.A.J., Jolliet O., Juraske R., Koehler A., Larsen H.F., MacLeod M., Margni M., McKone T.E., Payet J., Schuhmacher M., van de Meent D., Hauschild M.Z. 2008. USEtox-the UNEP-SETAC toxicity model: recommended characterisation factors for human toxicity and freshwater ecotoxicity in life cycle impact assessment. Int. J. Life Cycle Assess. 13:532-46.

Rosenbaum R.K., Huijbregts M.A.J., Henderson A.D., Margni M., McKone T.E., van de Meent D., Hauschild M.Z., Shaked S., Li D.S., Gold L.S., Jolliet O. 2011. USEtox human exposure and toxicity factors for comparative assessment of toxic emissions in life cycle analysis: sensitivity to key chemical properties. Int. J. Life Cycle Assess. 16:710-27.

Russu R., Vieri M. 2003. Macchine irroratrici agricole: controlli e tarature per una maggiore efficienza e sicurezza di impiego. Quaderno ARSIA n.5, Firenze, Italy.

Sacchelli S., Fabbrizzi S., Menghini S. 2016. Climate change, wine and sustainability: a quantitative discourse analysis of the international scientific literature. Agric. Agric. Sci. Procedia. 8:167-75.

Sarri D., D’Arcangelo M., Lisci R., Perria R., Rimediotti M., Storchi P., Valentini P., Vieri M. 2014. Analisi della variabilità del volume applicato nei diversi trattamenti annuali alla vite con irroratrice a recupero Bretoni. Atti Giorn. Fitopatol. 1:641-50.

Saxe H. 2010. LCA-based comparison of the climate footprint of beer vs. wine $\&$ spirits. Report n. 207. Institute of Food and Resource Economics, Copenhagen, Denmark.

Spugnoli P., Baldi F., Parenti A. 2009. An LCA model to asess the environmental improvement of new farming system. J. Agricult. Engine. 4:19-25.

Vázquez-Rowe I., Rugani B., Benetto E. 2013. Tapping carbon footprint variations in the European wine sector. J. Clean. Prod. 43:146-55. 